\title{
Tingkat Kualitas Permukiman (Studi Kasus: Permukiman Semitar Tambang Galian C Kecamatan Weru, Kabupaten SUKOHARJO)
}

\author{
LILIK ANJAR SETIAWAN ${ }^{1}$ \\ PROGRAM STUDI PERENCANAAN WILAYAH DAN KOTA \\ FAKULTAS TEKNIK \\ UNIVERSITAS SEBELLAS MARET, SURAKARTA \\ EMAIL : LILIKANJARSETIAWAN@GMAIL.COM \\ WINNY ASTUTI ${ }^{2}$ \\ PROGRAM STUDI PERENCANAAN WILAYAH DAN KOTA \\ FAKULTAS TEKNIK \\ UNIVERSITAS SEBELAS MARET, SURAKARTA \\ ERMa FITRIA RINI ${ }^{3}$ \\ PROGRAM STUDI PERENCANAAN WILAYAH DAN KOTA \\ FAKULTAS TEKNIK \\ UNIVERSitAs SEBELAS MARET, SURAKARTA
}

\begin{abstract}
Settlement is defined as a components combination of housing, environment and life of the societies who live in it. Quality of settlement components can describe how the condition of the settlement itself. Several settlement areas in Weru Subdistrict, Sukoharjo District have a C-type quarry location inside. Based on the Sukoharjo District Spatial Plan, that area is planned as settlement activities. There are other activities that should be supported by the components of the settlements that only planned to accommodate settlement activities. Question in this research is to know the level of settlement quality of each block in settlement area around C-type quarry in Weru Subdistrict seen from (1) nature, (2) shell, (3) infrastucture network, and (4) society. This research is a quantitative research using scoring analysis technique. The result shown that there is difference between each block of settlement. Block 2 has high quality because it has several components with high quality such as buildings, infrastructure network, and the level of public health. The other blocks such as block 1 , block 3, block 4, and block 5 have medium quality with several medium quality of components such as green space, road network, economic level and level of public health. Improvement are needed for some components to improve the quality of settlements in each block so that the whole settlements becomes better to lived.
\end{abstract}

Keywords: C-Type Mine; Quality; Quarry; Settlement; Settlement Component;

\section{PENDAHULUAN}

Kawasan permukiman menurut Undangundang Nomor 1 Tahun 2011 tentang Perumahan dan Kawasan Permukiman adalah bagian dari lingkungan hidup di luar kawasan lindung, baik berupa kawasan perkotaan maupun perdesaan, yang berfungsi sebagai lingkungan tempat tinggal atau lingkungan hunian dan tempat kegiatan yang mendukung perikehidupan dan penghidupan. Sedangkan permukiman sendiri adalah bagian dari lingkungan hunian yang terdiri lebih dari satu satuan perumahan yang mempunyai prasarana, sarana, utilitas umum, serta mempunyai penunjang kegiatan fungsi lain di kawasan perkotaan atau perdesaan.

Permukiman menurut Kuswartoyo, 2005 diartikan sebagai perpaduan perumahan dan kehidupan manusia yang 
menempatinya. Permukiman dapat diartikan pula paduan antara manusia dengan masyarakatnya, alam dan unsur buatan. Doxiadis, 1971 dalam Kuswartoyo, 2005 menerangkan unsurunsur permukiman yaitu alam (nature), lindungan(shell), jejaring (network), manusia (man), dan masyarakat (society). Komposisi unsur yang membentuk permukiman beraneka ragam, serta kegiatan yang ditampung oleh permukiman tersebut juga beragam. Selain untuk menampung kegiatan hunian itu sendiri, permukiman juga sebagai tempat kegiatan yang mendukung perikehidupan dan penghidupan salah satunya adalah kegiatan pertambangan. Fungsi permukiman dapat dilihat dari kondisi masing-masing unsur penyusunnya. Unsur atau komponen penyusun dapat menggambarkan bagaimana kondisi permukiman tersebut secara keseluruhan.

Beberapa kawasan permukiman di Kabupaten Sukoharjo memiliki kegiatan lain disamping kegiatan permukiman. Kegiatan lain tersebut berupa aktivitas penambangan bahan galian golongan $\mathbf{C}$ dengan produk tambang berupa tanah urug di Kecamatan Bendosari dan Desa Sanggang, tambang batu di Desa Pundungrejo dan Karangmojo, serta tambang batu kapur di Kecamatan Weru. Berdasarkan Rencana Tata Ruang Kabupaten Sukoharjo, kawasan permukiman tersebut merupakan kawasan dengan kegiatan permukiman. Ini berarti unsur atau komponen penyusun permukiman yang ada merupakan komponen yang direncanakan untuk mendukung kegiatan permukiman. Komponen tersebut mungkin dapat menampung sesuai kapasitasnya dalam mendukung kegiatan permukiman, akan tetapi bagaimana apabila komponen tersebut juga harus mendukung kegiatan lain seperti kegiatan pertambangan. Rusaknya infrastruktur jalan dan air bersih serta terbuka kesempatan bekerja bagi masyarakat merupakan hal-hal yang bersinggungan langsung dengan unsur permukiman. Dengan komponen yang harus melayani atau mendukung kegiatan lain disamping kegiatan permukiman itu sendiri, apakah komponen-komponen permukiman di kawasan tersebut masih berfungsi sebagaimana mestinya. Dilihat dari komponen-komponen tersebut, lalu bagaimana kualitas permukiman tersebut secara keseluruhan.

Melihat fakta-fakta di kawasan permukiman sekitar tambang tersebut dapat dirumuskan pertanyaan penelitian "Bagaimana tingkat kualitas permukiman studi kasus kawasan permukiman sekitar tambang galian golongan $C$ Kecamatan Weru, Kabupaten Sukoharjo?"

\section{TINJAUAN PUSTAKA}

Ditinjau dari struktur katanya, kata permukiman mengandung dua kata yang berbeda yaitu isi dan wadah. Isi menunjuk pada manusia sebagai penghuninya maupun masyarakat di lingkungan sekitarnya, sedangkan wadah menunjuk pada fisik hunian yang terdiri dari alam dan elemen-elemen buatan manusia. Permukiman dapat diimplementasikan sebagai suatu tempat bermukim manusia yang menunjukan suatu tujuan tertentu (Sastra, 2005). Dengan demikian permukiman harus memberikan rasa nyaman kepada penghuninya termasuk bagi orang yang datang ke tempat tersebut. Sifat dan karakter suatu permukiman lebih kompleks dibandingkan dengan sifat dan karakter dari perumahan karena mencakup batasan ruang lingkup dan luas yang lebih besar.

Doxiadis, 1971 dalam Kuswartojo, 2005 menerangkan unsur-unsur permukiman yaitu alam (nature), lindungan(shell), jejaring (network), manusia (man), dan masyarakat (society). Alam merupakan unsur dasar yang kemudian diatasnya didirikan bangunan atau rumah serta jejaringnya sebagai tempat tinggal manusia dan berbagai kegiatan lain.

Elemen-elemen permukiman terdiri dari beberapa unsur (Sastra, 2005) yaitu 1) 
Alam: geologi, topografi, tanah, air, tumbuh-tumbuhan, hewan, iklim, dan sebagainya. 2) Manusia. 3) Masyarakat: komposisi penduduk, kelompok sosial, adat dan kebudayaan, pengembangan ekonomi, pendidikan, kesehatan, serta hukum dan administrasi. 4) Bangunan. 5) Network: sistem jaringan air bersih, listrik, transportasi, komunikasi, drainase dan air kotor, serta tata letak fisik.

Dursun \& Saglamer (2009) mengemukakan bahwa yang menjadi perhatian penting dalam mengenai kualitas permukiman adalah 1) Contextual Aspect: karakteristik alami, pengelolaan kenyamanan lingkungan, keamanan, lokasi permukiman, dan aksesibilitas. 2) Spatial Aspect: karakteristik arsitektural, ukuran bangunan, dan organisasi spasial. 3) Social Aspect: profil masyarakat, interaksi sosial masyarakat, integrasi sosial penduduk dengan lingkungan, organisasi sosial dan administratif. 4) Economic Aspect: kemampuan masyarakat memiliki hunian, kepemilikan hunian permanen, dan preferensi hunian.

Menurut Ditjen Cipta Karya Departemen Pekerjaan Umum (1980) dalam Yuniawan (2011), terdapat faktor-faktor yang bisa dijadikan penimbang parameter kualitas permukiman, yaitu kepadatan bangunan, lebar jalan masuk permukiman, tata letak bangunan, kondisi permukaan jalan masuk permukiman, pohon pelindung jalan, lokasi permukiman, kualitas atap bangunan.

Ridwan \& Giyarsih (2012) mengemukakan bahwa kualitas suatu lingkungan permukiman dapat diukur dengan melihat beberapa indikator. Kualitas lingkungan permukiman dinilai berdasarkan indikator komposit yang merupakan gabungan dari tiga indikator yaitu kondisi rumah, sanitasi lingkungan, dan prasarana dasar permukiman.

Menurut Ekartaji at al (2014), untuk mengkaji sebaran kualitas lingkungan permukiman diukur dengan melihat kondisi fisik bangunan dan sosial ekonomi masyarakat yang menempatinya. Fisik bangunan yang dilihat adalah terkait keteraturan bangunan serta kondisi kontruksi bangunan itu sendiri. Keteraturan bangunan yang dimaksud adalah kondisi arah hadap dan bentuk bangunan. Semakin seragam kondisi arah hadap serta ukuran suatu bangunan dengan bangunan-bangunan lain disekitarnya maka keteraturannya semakin baik. Sedangkan kondisi kontruksi bangunan dilihat dari beberapa hal seperti kondisi atap dan dinding bangunan serta ukuran bangunan. Kondisi sosial ekonomi masyarakat yang digunakan untuk melihat kualitas lingkungan permukiman adalah tahun sukses pendidikan, tingkat pendapatan, dan tingkat partisipasi masyarakat dalam pembangunan lingkungan permukiman yang ditinggalinya.

\section{METODE PENELITIAN}

Penelitian ini dilakukan pada permukiman sekitar tambang galian $\mathbf{C}$ yang ada di Kecamatan Weru, Kabupaten Sukoharjo. Area yang digunakan adalah persebaran permukiman dengan radius 500 meter dari lokasi-lokasi tambang. Hal tersebut merujuk pada Keputusan Menteri Pertambangan dan Energi No. 523 K/201/MPE/1992 tentang pedoman teknis penyusunan penyajian informasi lingkungan, rencana pengelolaan lingkungan dan rencana pemantauan lingkungan untuk usaha pertambangan bahan galian golongan $\mathrm{C}$, bahwa lokasi tambang galian $\mathrm{C}$ dengan luas wilayah pertambangan hingga $25 \mathrm{Ha}$ di sungai memiliki hubungan dengan sumberdaya dan kegiatan lain yang berada sekurangkurangnya $5 \mathrm{Km}$ ke arah hulu dan $5 \mathrm{Km}$ ke arah hilir serta jarak 500 meter dari sempadan sungai. Sedangkan menurut Keputusan Menteri Pertambangan dan Energi NO. 555/K/26/MPE/1995 menyebutkan bahwa daerah pemboran eksplorasi harus memperhatikan keadaan 
daerah dalam radius 500 meter dari batas kuasa pertambangan.

Kawasan permukiman tersebut dibagi kedalam 5 blok yang memiliki kesamaan fungsi, keadaan fisik, dan lingkungan alami kawasan tersebut. Area penelitian seperti yang terlihat pada Gambar 1.

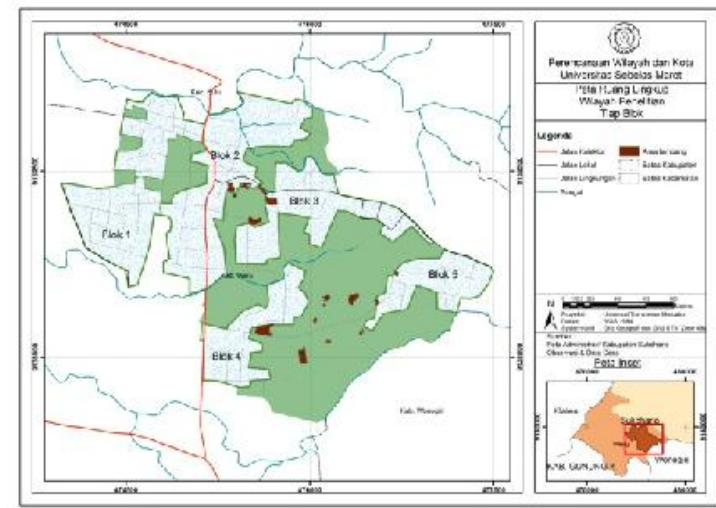

Gambar 1 Peta Wilayah Penelitian

Penelitian ini menggunakan pendekatan deduktif yaitu pendekatan yang menggunakan dasar teori yang sudah ada sebelumnya. Teori-teori yang ada kemudian memunculkan pertanyaan penelitian yang kemudian akan diuji. Dari teori-teori tersebut juga akan menurunkan variabel dan diukur dengan indikator-indikator yang didapatkan. Variabel, subvariabel, dan indikator dalam penelitian ini dapat dilihat pada Lampiran A.

Teknik analisis yang digunakan pada penelitian ini adalah teknik analisis skoring. Data-data yang didapatkan diperoleh melalui observasi, citra satelit, studi literatur, wawancara dengan perangkat desa setempat, serta hasil kuisioner yang dibagikan terhadap beberapa warga sebagai sampel. Teknik sampling yang digunakan adalah probability sampling dengan jumlah sampel yang didapatkan sebanyak 105 orang yang terbagi pada 5 blok permukiman. Masing-masing blok diambil jumlah sampel yang berbeda sesuai dengan besarnya jumlah penduduk. Blok 1 terdiri dari 33 responden, blok 2 terdiri dari 32 responden, blok 3 terdiri dari 13 responden, blok 4 terdiri dari 21 responden, dan blok 5 terdiri dari 7 responden.

Pada variabel tingkat kesehatan dinilai menggunakan tingkat Incident Rate (IR). Nilai IR didaptkan dari jumlah kejadian penyakit atau penderitapenyakit dalam kurun waktu satu tahun di suatu kawasan dibandingkan dengan jumlah penduduk di kawasan tersebut. Hasil perhitungan IR kemudian diklasifikasikan dengan interval yang didapatkan dari nilai IR tertinggi dikurangi nilai IR terendah dibagi 3 kelas.

Masing-masing variabel dari masingmasing blok dinilai berdasarkan indikator yang ada berdasarkan tingkat kualitas tinggi, sedang, atau rendah. Kualitas tinggi diberi nilai 3 , kualitas sedang diberi nilai 2 , sedangkan kualitas rendah diberi nilai 1 . Setelah didapatkan nilai total dari masing-masing blok, kemudian disesuaikan dengan interval tingkat kualitas tinggi, sedang, dan rendah. Interval tingkat kualitas didapatkan dari total nilai maksimal yang dapat diperoleh dikurangi total nilai minimal yang dapat diperoleh kemudian dibagi dengan jumlah kelas dalam hal ini sebanyak 3 kelas. Nilai maksimal yang mungkin didapatkan per blok adalah 42 sedangkan nilai minimalnya adalah 14 . Dari perhitungan didapatkan kelas pertama adalah $14-22$ tergolong blok dengan tingkat kualitas rendah. Kelas kedua adalah 23-31 menunjukan tingkat kualitas sedang serta kelas $32-42$ menunjukan tingkat kualitas tinggi.

\section{HASIL DAN PEIMBAHASAN}

Berdasar pada hasil analisis, maka dapat dijabarkan mengenai pembahasan terkait dengan analisis skoring pada masing-masing variabel. Hasil analisis tingkat kualitas permukiman di sekitar tambang galian C Kecamatan Weru dapat dilihat pada Lampiran B.

Dari hasil analisis didapatkan bahwa blok 4 memiliki nilai yang terendah dengan tingkat kualitas yang tergolong sedang. Selain blok 4, blok-blok lain yang memiliki kualitas sedang adalah blok 1 , blok 3, dan blok 5. Sedangkan blok 2 
memiliki nilai tertinggi dibandingkan dengan blok lain serta memiliki tingkat kualitas yang tinggi.

Komponen permukiman yang memiliki kualitas sama diantara kelima blok adalah komponen kepadatan bangunan, tata letak bangunan, jaringan drainase, interaksi sosial dan kelompok sosial. Komponen-komponen tersebut memiliki nilai yang tergolong tinggi pada tiap-tiap blok permukiman. Komponen lain yang memiliki nilai sama diantara kelima blok tersebut adalah komponn tingkat ekonomi, dan tingkat pendidikan. Komponen tingkat ekonomi tergolong rendah memiliki nilai 1 di tiap blok sedangkan tingkat pendidikan tergolong sedang dengan nilai 2 pada tiap blok.

Ketersediaan ruang terbuka hijau di kawasan ini umumnya tergolong rendahpada tiap-tiap blok. Hal ini dikarenakan penggunaan lahan di kawasan ini mayoritas digunakan sebagi tegalan ataupun masih berupa semak atau perdu yang belum termanfaatkan. Bahkan, luas area tegalan dan semak tersebut lebih tinggi dibandingkan dengan luas area terbangun yang ada di kawasan ini. Ruang terbuka hijau yang ada hanya berupa RTH yang merupakan fasilitas olahraga dan pemakaman. Hal ini yang menyebabkan luasan RTH pada masing-masing blok di kawasan ini tergolong rendah. Persebaran ruang terbuka hijau di kawasan ini dapat dilihat pada Gambar 2.

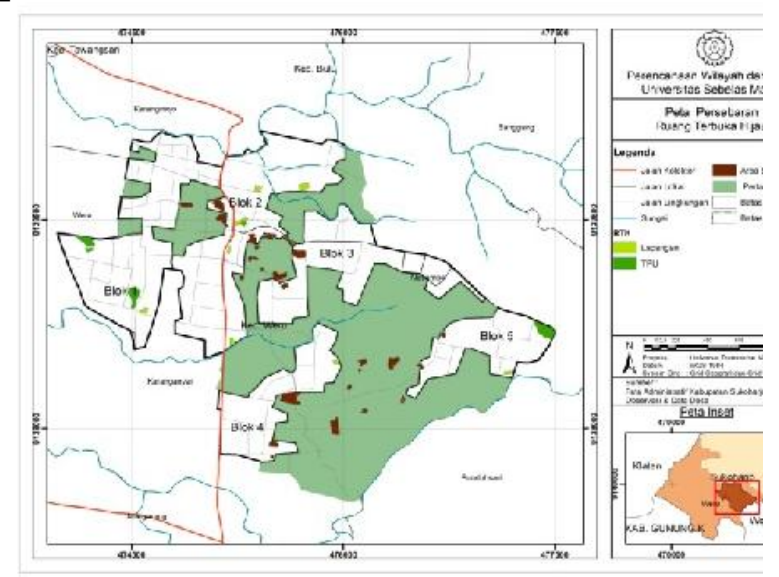

Gambar 2. Peta Persebaran Ruang Terbuka Hijau
Sumber: Peneliti, 2017

Komponen jaringan air bersih di tiap blok memiliki nilai yang rendah di hampir seluruh blok permukiman. $\mathrm{Hal}$ ini dikarenakan kondisi kawasan yang memiliki wilayah dengan berbeda ketinggiannya. Lokasi tambang yang umumnya terletak di bagian yang lebih tinggi menyebabkan sisa tambang terbawa aliran air menuju daerah dibawahnya sehingga mencemari sumber air bersih warga. Blok permukiman yang kondisi airnya keruh adalah pada blok 1, blok 2, blok 4, dan sebagian blok 3 . Blok-blok tersebut memiliki ketinggian tanah yang relatif lebih rendah dibandingkan blok 5. Aliran air dari tempat yang lebih tinggi yang juga melewati area tambang membawa material sisa aktivitas tersebut hingga mengalir mencemari sumber air warga yang berada di tempat yang lebih rendah.

Dimensi jalan yang ada di kawasan ini memiliki nilai yang hampir sama di tiap blok permukiman yaitu bernilai rendah. Akan tetapi dimensi jalan di pada blok 2 memiliki nilai yang tertinggi. Ruas jalan di blok ini merupakan jalan alternatif penghubung Kabupaten Sukoharjo dengan Kabupaten Gunungkidul sehingga memiliki dimensi jalan yang relatif lebih lebar dibandigkan dengan ruas jalan di blok lain. Sedangkan kondisi jalan di tiap blok memiliki kualitas yang berbeda. Ruas jalan di blok 2 dan blok 3 mimiliki nilai yang tertinggi dengan nilai 3. Sedangkan nilai yang terendah berada pada blok 4 dan blok 5 yang memiliki lokasi yang relatif dekat dengan lokasi tambang. Aktivitas tambang yang ada di dekat blok ini juga mempengaruhi bagaimana kondisi jalan yang ada. Kondisi ruas jalan di kawasan ini dapat dilihat pada Gambar 3. 


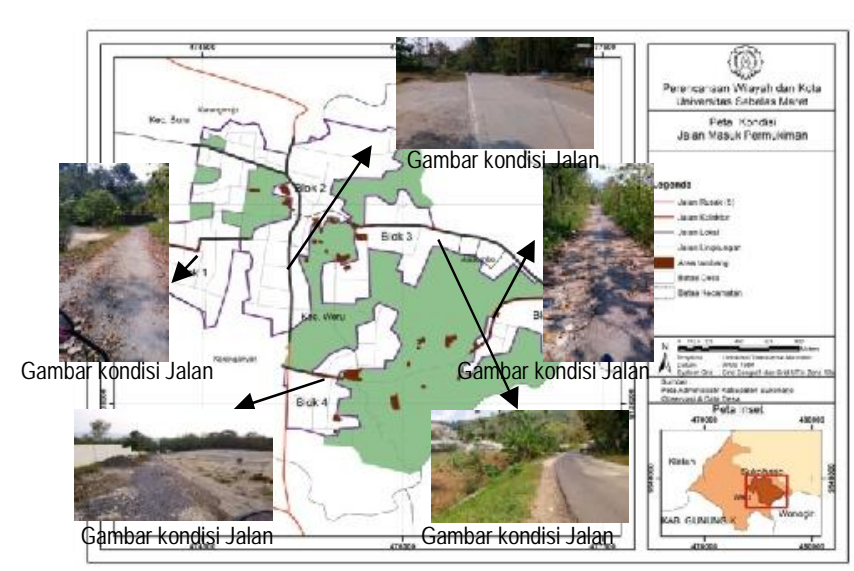

Gambar 3. Peta Kondisi Jalan Masuk Permukiman

Sumber: Peneliti, 2017

Kondisi jaringan drainase di kawasan ini relatif sama pada tiap blok permukiman yaitu tergolong memiliki kualitas yang tinggi. Kinerja jaringan drainase yang relatif baik sehingga tidak ada genangan yang terjadi di dalam kawasan permukiman ini. Disamping itu, hal ini terjadi karena topografi kawasan yang relatif berbukit sehingga air hujan yang jatuh bisa langsung mengalir ke area yang lebih rendah tanpa menggenang di kawasan ini.

Kondisi jaringan sanitasi dan jaringan listrik di kawasan ini memiliki nilai yang bervariasi di tiap blok permukiman. Blok permukiman yang memiliki nilai jaringan sanitasi dan jaringan listrik yang terendah ada di blok 4 yang masingmasing memiliki nilai 1 . Kondisi jaringan sanitasi dan jaringan listrik yang relatif tidak terlalu tinggi di kawasan ini terkait dengan tingkat ekonomi yang relatif rendah. Warga yang memiliki pendapatan tergolong rendah akan lebih sulit untuk memenuhi kebutuhannya akan jaringan sanitasi dan jaringan listrik.

Tingkat ekonomi masyarakat yang tinggal di kawasan permukiman ini

\section{KESIMPULAN}

Kesimpulan dan saran yang didapatkan dari hasil penelitian ini adalah sebagai berikut.

\subsection{Kesimpulan}

tergolong rendah pada seluruh blok permukiman yang ada. $\mathrm{Hal}$ ini dikarenakan pekerjaan mayoritas penduduk adalah bekerja sebagai petani yang meengelola lahan miliki orang lain. Kebanyakan dari masyarakat di kawasan ini hanya sebagai buruh ataupun penggarap sawah milik orang lain yang nantinya hasil panen yang didapatkan harus dibagi dua dengan pemilik lahan sehingga pendapatan petani di kawasan ini menjadi relatif rendah.

Tingkat kesehatan masyarakat di kawasan permukiman ini relatif bervariasi pada tiap blok permukiman. Blok 3, blok 4, dan blok 5 tingkat kesehatan masyarakat yang relatif lebih rendah dibandingkan dengan blok lain. Blok-blok ini memiliki lokasi yang relatif dekat dengan lokasi tambang. Jumlah penderita penyakit pernafasan di blok ini yang relatif tinggi mungkin disebabkan oleh aktivitas tambang yang jaraknya terlalu dekat dengan rumah-rumah warga. Sisa bahan tambang serta polusi dari aktivitas tersebut akan langsung menuju rumah-rumah warga sehingga mempengaruhi kesehatan warga di blok tersebut.

Interaksi antar masyarakat di kawasan ini relatif tinggi. interaksi yang relatif tinggi ini terjadi di seluruh blok permukiman. Intensitas interaksi antar warga hampir terjadi setiap hari. Hal ini dikarenakan kawasan ini masih memiliki ciri perdesaan dimana warganya masih memiliki sifat guyub yang tinggi. selain itu, pekerjaan penduduk yang kebanyakan sama yaitu sebagai petani mempermudah mereka untuk menyesuaikan waktu untuk saling berbincang dan bertukar informasi sehingga intensitas interaksi menjadi tinggi.

Berdasarkan hasil penelitian, tingkat kualitas permukiman di sekitar tambang galian C Kecamatan Weru memiliki kondisi yang hampir sama pada tiap blok. Blok 1, blok 3, blok 4, dan blok 5 memiliki kualitas yang tergolong sedang, sedangkan blok 2 memiliki kualitas yang 
tinggi. ini artinya permukiman di kawasan ini secara keseluruhan memiliki rata-rata tingkat kualitas yang sedang. Beberapa komponen permukiman masih memiliki kualitas rendah meskipun secara keseluruhan kualitas pada masing-masing blok tergolong sedang hingga tinggi. Komponen-komponen yang memiliki kualitas rendah pada tiap blok adalah ruang terbuka hijau dan tingkat ekonomi. Komponen-komponen yang memiliki kualitas sedang pada tiap blok adalah tingkat pendidikan dan kelompok sosial. Sedangkan komponenkomponen yang memiliki kualitas tinggi pada tiap blok adalah kepadatan dan tata letak bangunan, jaringan drainase, dan interaksi sosial.

Kualitas komponen ruang terbuka hijau di kawasan ini tergolong rendah karena lahan yang ada mayoritas digunakkan sebagai tegalan ataupun semak yang belum dimanfaatkan. Sedangkan ruang terbuka hijau yang dimaksud dalam penelitian ini adalah ruang terbuka yang tidak hanya bersifat pasif seperti halnya tegalan dan semak. Selain komponen ruang terbuka hijau, komponen tingkat ekonomi juga tergolong memiliki kualitas rendah. Hal ini dikarenakan pekerjaan mayoritas penduduk adalah petani yang mengelola lahan bukan miliknya sendiri melainkan lahan milik. Petani dikawasan ini menggarap lahan milik orang lain dengan imbalan harus membagi hasil panen dengan pemilik lahan sehingga pendapatan mereka menjadi relatif rendah.

Kualitas komponen bangunan di kawasan ini tergolong tinggi. Ketersediaan lahan yang masih tergolong tinggi menyebabkan pembangunan yang dilakukan lebih mudah disesuaikan tanpa terkendala keterbatasan ruang. Hal ini yang mengkibatakan kepadatan dan tata letak bangunan di kawasan ini memiliki kualitas yang tinggi. Komponen jaringan drainase di kawasan ini tergolong memiliki kualitas tinggi. $\mathrm{Hal}$ ini dikarenakan topografi kawasan yang berbukit sehingga air hujan yang turun akan bisa langsung mengalir menuju area yang lebih rendah. Akibatnya, tidak terjadi genangan di kawasan permukiman ini. Selain komponenkomponen tersebut, komponen lain yang memiliki kualitas tinggi adalah komponen interaksi sosial. Hal ini dikarenakan kawasan ini masih memiliki ciri perdesaan dimana warganya masih memiliki rasa guyub yang tinggi.

\subsection{Saran}

Saran yang direkomendasikan dari hasil penelitian ini adalah sebagai berikut.

a. Pengelolaan atau pengembangan permukiman harus memperhatikan kualitas komponen-komponen penyusun permukiman agar kualitas permukiman yang ada tergolong tinggi sehingga meningkatkan kesejahteraan masyarakat yang tinggal di kawasan permukiman tersebut.

b. Untuk kondisi komponen permukiman yang sudah ada saat ini perlu ditingkatkan terutama pada komponen yang kualitasnya rendah dan sedang. Komponen-komponen tersebut antara lain ketersediaan RTH, kualitas sumber air bersih, kondisi jaringan jalan, penyediaan jaringan listrik, tingkat pendidikan dan kelompok masyaraka. Sedangkan komponen permukiman dengan kualitas yang tinggi harus terus dipertahankan atau bahkan ditingkatkan lagi agar kualitas permukiman di kawasan tersebut semakin baik lagi. Komponen tersebut antara lain tata letak bangunan, kinerja jaringan drainase, dan interaksi sosial masyarakatnya.

c. Perencanaan kawasan permukiman juga harus memperhatikan kondisi atau aktivitas yang ada didalam dan sekitar kawasan secara komprehensif. Setiap aktivitas harus dapat diwadahi oleh kawasan permukiman tersebut sepanjang masih sesuai dengan daya dukung dan daya tampung lingkungan di kawasan itu agar tidak mengganggu 
aktivitas lain yang juga ada di kawasan permukiman tersebut.

\section{DAFTAR PUSTAKA}

Anisa, Hana Hilaly. 2016. Alih Fungsi Lahan dan Tingkat Kohesi Sosial Masyarakat Pedesaaan. Intitut Pertanian Bogor. Bogor.

Balai Perumahan dan Lingkungan Puslitbang Permukiman Badan Penelitian dan Pengembangan Kementerian Pekerjaan Umum dan Perumahan Rakyat. 2012. Penentuan Tingkat Kekumuhan Kawasan Padat Huni-Kumuh Perkotaan. http://puskim.pu.go.id/aplikasi/ku muh/. Diakses pada 10 Juli 2017 pukul 10.00 WIB.

Departemen Permukiman dan Prasarana Wilayah. 2004. Pedoman Kontruksi dan Bangunan: Penentuan Klasifikasi Fungsi Jalan di Kawasan Perkotaan.

Direktorat Pengembangan Permukiman Direktoral Jenderal Cipta Karya Departemen Pekerjaan Umum. 2006. Pedoman Indentifikasi Kawasan Permukiman Kumuh Daerah Penyangga Kota Metropolitaan.

Dursun, Pelin \& Saglamer, Gulsun. 2009. Analysing Housing Quality: Balerko Housing Settlement, Trabzon, Turkey. Open House International Vol. 23 No. 4.

Ekartaji, Prittaningtyas dkk. 2014. Kajian Kualitas Lingkungan Permukiman di Daerah Pinggiran Kota Kasus di Desa Ngestiharjo, Yogyakarta. Majalah Geografi Indonesia Vol. 28, No. 1. Universitas Gadjah Mada. Yogyakarta.

Keputusan Menteri Pertambangan dan Energi No. 555/K/26/MPE/1995 Tahun 1995.

Keputusan Menteri Negara Lingkungan Hidup No. 43 Tahun 1996 tentang kriteria kerusakan lingkungan hidup bagi usaha atau kegiatan penambangan bahan galian golongan $C$ jenis lepas daratan

Kuswartojo, Tjuk et al. (2005). Perumahan dan Permukiman di Indonesia. Bandung: ITB.
Peraturan Menteri Kesehatan Nomor 492/Menkes/Per/2010 tentang Persyaratan Kualitas Air Minum.

Peraturan Menteri Pekerjaan Umum Nomor 01 Tahun 2014 tentang Standar Pelayanan Minimal Bidang Pekerjaan Umum dan Penataan Ruang.

Peraturan Menteri Pekerjaan Umum No:05/PRT/M/2008 tentang Pedoman Penyediaan dan Pemanfaatan Ruang Terbuka Hijau di Kawasan Perkotaan.

Priyono, et al. 2013. Pengukuran Kualitas Permukiman Hubungannya dengan Tingkat Kesehatan Masyarakat di Kecamatan Sragen: Upaya Awal Untuk Peningkatan Kapasitas Masyarakat dalam Strategi Pengurangan Resiko Penyakit. Universitas Muhamadiyah Surakarta. Sukoharjo.

Ridwan, Ucok Heriady \& Giyarsih, Sri Rum. 2012. Kualitas Lingkungan Permukiman Masyarakat Suku Bajo di Daerah yang Berkarakter Pinggiran Kota dan Daerah Berkarakter Pedesaan di kabupaten Muna. Jurnal Pembangunan Wilayah \& Kota, Vol. 8(2):118-125 Juni 2012. Universitas Dipenegoro. Semarang.

Sastra, Suparno \& Marlina, Endy. (2005). Perencanaan dan Pengembangan Perumahan. Yogyakarta: Andi.

Standar Nasional Indonesia No. SNI 031733-2004 tentang Tata Cara Perencanaan Lingkungan Perumahan di Perkotaan.

UN. 2015. Millennium Develompment Goals. http://www.un.org diakses 20 September, pukul 02.00 WIB

UN. 2015. Sustainable Develompment Goals.

https://sustainabledevelopment.un .org/sdgs diakses 20 September, pukul $02.00 \mathrm{WIB}$

Undang-undang Nomor 1 Tahun 2011 tentang Perumahan dan Kawasan Permukiman

World Bank. 2006. Indonesia Making the New Indonesia Work for the Poor. Poverty Reduction and Economic 
Management Sector Unit. East Asia and Pacific Region.

Yuniawan, Rahmad. 201 1. Analisis Kondisi Kualitas Lingkungan Permukiman Menggunakan Citra Quickbird di
Kecamatan Depok Kabupaten Sleman. Skripsi thesis, Universitas Muhammadiyah Surakarta. 


\section{LAMPIRAN}

Lampiran A Tabel Variabel, Subvariabel, Indikator Penelitian Tingkat Kualitas Permukiman Sekitar Tambang Galian C di Kecamatan Weru

\begin{tabular}{|c|c|c|c|}
\hline Variabel & Subvariabel & Indikator & Sumber \\
\hline $\begin{array}{l}\text { Lingkungan } \\
\text { Alam }\end{array}$ & $\begin{array}{l}\text { Ruang Terbuka } \\
\text { Hijau } \\
\text { (green space) }\end{array}$ & $\begin{array}{l}\text { - Rendah: <20\% kawasan merupakan RTH } \\
\text { - Sedang: } 20 \% \text { - 30\% kawasan merupakan RTH } \\
\text { - Tinggi: >30\% kawasan merupakan RTH }\end{array}$ & $\begin{array}{l}\text { Peraturan Menteri } \\
\text { Pekerjaan Umum No. } \\
\text { 05/PRT/M/2008 }\end{array}$ \\
\hline \multirow[t]{2}{*}{ Bangunan } & $\begin{array}{l}\text { Kepadatan } \\
\text { Bangunan }\end{array}$ & $\begin{array}{l}\text { - Rendah: kepadatan rumah atau bangunan rata-rata } \\
\text { pada suatu unit permukiman termasuk padat } \\
\text { (kepadatan }>100 \text { unit/Ha) } \\
\text { - Sedang: kepadatan rumah atau bangunan rata-rata } \\
\text { pada suatu unit permukiman termasuk sedang } \\
\text { (kepadatan } 60-100 \text { unit/Ha) } \\
\text { - Tinggi: kepadatan rumah atau bangunan rata-rata } \\
\text { pada suatu unit permukiman termasuk jarang } \\
\text { (kepadatan }<60 \text { unit/Ha) }\end{array}$ & $\begin{array}{ll}\text { Direktorat } & \\
\text { Pengembangan } \\
\text { Permukiman } & \text { Dirjen } \\
\text { Cipta } & \text { Karya } \\
\text { Departemen } & \\
\text { Pekerjaan Umum, } \\
2006\end{array}$ \\
\hline & $\begin{array}{ll}\text { Tata } & \text { Letak } \\
\text { Bangunan } & \end{array}$ & $\begin{array}{l}\text { - Rendah: }>75 \% \text { bangunan yang ada di kawasan tidak } \\
\text { tertata dengan teratur } \\
\text { - Sedang: } 60 \%-75 \% \text { bangunan yang ada di kawasan } \\
\text { tidak tertata teratur } \\
\text { - Tinggi: }<60 \% \text { bangunan yang ada di kawasan tidak } \\
\text { tertata teratur }\end{array}$ & $\begin{array}{l}\text { Balai Perumahan } \\
\text { dan Lingkungan } \\
\text { Puslitbang } \\
\text { Permukiman, } 2012\end{array}$ \\
\hline \multirow[t]{6}{*}{$\begin{array}{l}\text { Jaringan } \\
\text { Prasarana }\end{array}$} & $\begin{array}{l}\text { Jaringan } \\
\text { Bersih }\end{array}$ & $\begin{array}{l}\text { - Rendah: sumber air bersih berbau, berwarna, dan } \\
\text { berasa } \\
\text { - Sedang: sumber air bersih memiliki salah satu sifat } \\
\text { yaitu berbau, berwarna, atau berasa. } \\
\text { - Tinggi: sumber air bersih tidak berbau, tidak } \\
\text { berwarna, dan tidak berasa }\end{array}$ & $\begin{array}{l}\text { Peraturan } \text { Menteri } \\
\text { Kesehatan Nomor } \\
492 / \text { Menkes/Per/20 } \\
10 \quad \text { mengenai } \\
\text { persyaratan kualitas } \\
\text { air minum }\end{array}$ \\
\hline & Jaringan Jalan & $\begin{array}{l}\text { - Rendah: lebar jalan masuk rata-rata }<6,5 \mathrm{~m} \\
\text { - Sedang: lebar jalan masuk rata-rata sama dengan } 6,5 \\
\text { m } \\
\text { - Tinggi: lebar jalan masuk rata-rata }>6,5 \mathrm{~m}\end{array}$ & $\begin{array}{l}\text { Departemen } \\
\text { Permukiman dan } \\
\text { Prasarana Wilayah, } \\
2004\end{array}$ \\
\hline & & $\begin{array}{l}\text { - Rendah: <60\% ruas jalan dalam kondisi baik } \\
\text { - Sedang: } 60 \%-80 \% \text { ruas jalan dalam kondisi baik } \\
\text { - Tinggi: }>80 \% \text { ruas jalan dalam kondisi baik }\end{array}$ & $\begin{array}{lr}\text { Peraturan } & \text { Menteri } \\
\text { Pekerjaan } & \text { Umum } \\
\text { Nomor } 01 & \text { Tahun } \\
2014 & \\
\end{array}$ \\
\hline & Jaringan Drainase & $\begin{array}{l}\text { - Rendah: }>50 \% \text { wilayah mengalami genangan } \\
\text { - Sedang: } 25 \%-50 \% \text { wilayah mengalami genangan } \\
\text { - Tinggi: <25\% wilayah mengalami genangan }\end{array}$ & $\begin{array}{ll}\text { Ditjen Cipta } & \text { Karya } \\
\text { Departemen } & \\
\text { Pekerjaan } & \text { Umum } \\
(2006) & \\
\end{array}$ \\
\hline & Jaringan Sanitasi & $\begin{array}{l}\text { - Rendah: terdapat keluarga yang tidak memiliki MCK } \\
\text { pribadi serta di wilayah tersebut tidak tersedia MCK } \\
\text { komunal } \\
\text { - Sedang: terdapat keluarga yang tidak memiliki MCK } \\
\text { pribadi akan tetapi di wilayah tersebut memiliki MCK } \\
\text { komunal } \\
\text { - Tinggi: seluruh keluarga di wilayah tersebut memiliki } \\
\text { MCK pribadi }\end{array}$ & $\begin{array}{l}\text { UN(2015): } \\
\text { Sustainable } \\
\text { Devlopment Goals } \\
\text { (SDGs) }\end{array}$ \\
\hline & Jaringan Listrik & $\begin{array}{l}\text { - Rendah: terdapat rumah yang belum teraliri daya } \\
\text { listrik } \\
\text { - Sedang: rata-rata rumah warga dialiri listrik dengan } \\
\text { daya 450VA atau dibawahnya } \\
\text { - Tinggi: rata-rata rumah warga dialiri listrik dengan } \\
\text { daya diatas } 450 \mathrm{VA}\end{array}$ & $\begin{array}{lr}\text { Standar } & \text { Nasional } \\
\text { Indonesia } & \text { (SNI) } \\
\text { Nomor } & \text { 03-1733- } \\
2004 & \end{array}$ \\
\hline \multirow[t]{3}{*}{ Masyarakat } & Tingkat ekonomi & $\begin{array}{l}\text { - Rendah: mayoritas pendapatan rata-rata masyarakat } \\
\text { dibawah Rp.800.000,- tiap bulan } \\
\text { - Sedang: mayoritas pendapatan rata-rata masyarakat } \\
\text { antara Rp.800.000,- sampai Rp. 1.300.000,- tiap bulan } \\
\text { - Tinggi: mayoritas pendapatan rata-rata masyarakat } \\
\text { diatas Rp.1.300.000,- tiap bulan }\end{array}$ & World Bank (2006), \\
\hline & $\begin{array}{l}\text { Tingkat } \\
\text { kesehatan }\end{array}$ & $\begin{array}{l}\text { - Rendah: hasil analisis Incident Rate menunjukan kelas } \\
\text { tertinggi } \\
\text { - Sedang: hasil analisis Incident Rate menunjukan kelas } \\
\text { menengah } \\
\text { - Tinggi: hasil analisis Incident Rate menunjukan kelas } \\
\text { terendah }\end{array}$ & Priyono et al, 2013 \\
\hline & $\begin{array}{l}\text { Tingkat } \\
\text { pendidikan }\end{array}$ & $\begin{array}{l}\text { - Rendah: warga di wilayah tersebut rata-rata tidak } \\
\text { tamat SD }\end{array}$ & $\begin{array}{l}\text { UN(2015): } \\
\text { Millennium }\end{array}$ \\
\hline
\end{tabular}




\begin{tabular}{|c|c|c|c|}
\hline Variabel & Subvariabel & Indikator & Sumber \\
\hline & & $\begin{array}{l}\text { - Sedang: warga di wilayah tersebut rata-rata memiliki } \\
\text { pendidikan terakhir SD hingga SMP } \\
\text { - Tinggi: warga di wilayah tersebut rata-rata memiliki } \\
\text { pendidikan terakhir SMA atau lebih tinggi }\end{array}$ & $\begin{array}{l}\text { Development Goals } \\
\text { (MDGs) }\end{array}$ \\
\hline & Interaksi sosial & $\begin{array}{l}\text { - Rendah: tidak terjadi tatap muka antar warga dalam } \\
\text { kurun waktu satu pekan } \\
\text { - Sedang: terjadi satu sampai dua kali tatap muka antar } \\
\text { warga dalam kurun waktu satu pekan } \\
\text { - Tinggi: terjadi lebih dari dua kali tatap muka antar } \\
\text { warga dalam kurun waktu satu pecan }\end{array}$ & Anisa, 2016 \\
\hline & Kelompok sosial & $\begin{array}{l}\text { - Rendah: tidak terdapat kelompok sosial masyarakat } \\
\text { yang memiliki aktivitas yang berkaitan dengan } \\
\text { lingkungan } \\
\text { - Sedang: terdapat kelompok sosial masyarakat yang } \\
\text { memiliki aktivitas dibidang lingkungan tetapi tidak } \\
\text { rutin } \\
\text { - Tinggi: terdapat kelompok sosial masyarakat yang } \\
\text { memiliki aktivitas dibidang lingkungan secara rutin }\end{array}$ & $\begin{array}{l}\text { Dursun \& Saglamer } \\
\text { (2009) }\end{array}$ \\
\hline
\end{tabular}

Sumber :Kompilasi Peneliti dari Berbagai Sumber, 2017

Lampiran B Gambar Diagram Batang Tingkat Kualitas Permukiman Tiap Blok Permukiman

\section{Tingkat Kualitas Permukiman Tiap Blok Permukiman}

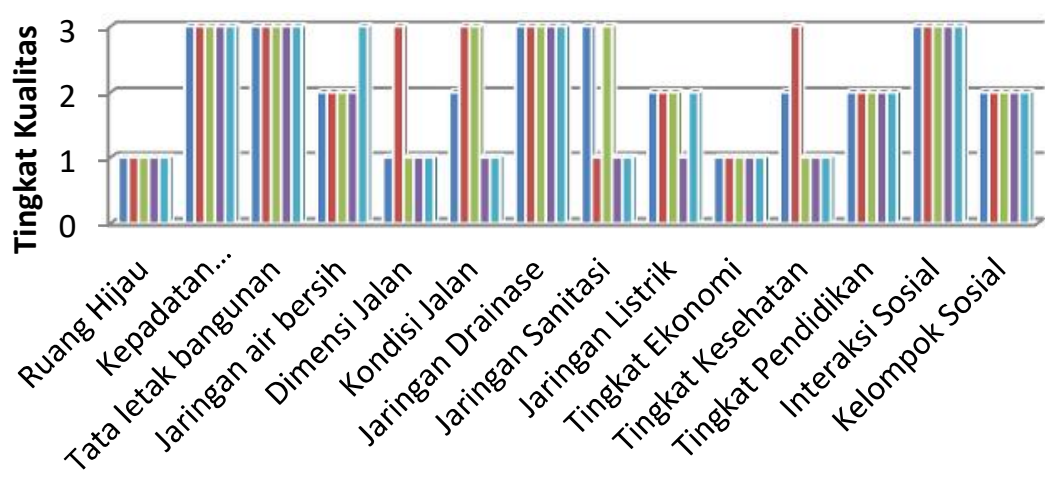

- Blok 1 (Nilai=30)

- Blok 2 (Nilai=32)

Blok 3 (Nilai=30)

Blok 4 (Nilai=25)

Blok 5 (Nilai=27)

Variabel Kualitas Permukiman

Sumber: Peneliti, 2017 